\title{
Volatile Organic Sulfur Compounds in Petroleum Accumulations in the Santos Basin, Brazil
}

\author{
IgOr V. A. F. SOUZA ${ }^{1 *}$, AlEXANDre A. FERrEIRA ${ }^{1}$, \\ GEOFFREY S. ElLIS ${ }^{2}$, RUT A. DÍAZ ${ }^{3}$, ANA LUIZA S. \\ ALBUQUERQUE ${ }^{3}$
}

${ }^{1}$ Petrobras, R\&D Center, Division of Geochemistry, Rio de Janeiro, RJ, Brazil (*igorviegas@petrobras.com.br, alexandreaf@petrobras.com.br)

${ }^{2}$ U.S. Geological Survey (USGS), Energy Resources Program, Denver, CO, USA (gsellis@usgs.gov)

${ }^{3}$ Fluminense Federal University (UFF), Geoscience Program (Geochemistry), Niteroi, RJ, Brazil (rutdiaz@id.uff.br, ana_albuquerque@id.uff.br)

Volatile organosulfur compounds (VOSC) and $\mathrm{H}_{2} \mathrm{~S}$ are toxic and corrosive and increase the cost of petroleum exploration, production and refining. However, there are few studies about VOSC molecular distribution in oil accumulations and their possible applications [1]. The objective of this work is to present the VOSC molecular distribution in petroleum reservoirs of the Santos Basin and to explore possible applications to petroleum systems studies. Sixty-four natural gas samples were analyzed to obtain the molecular distribution and carbon and hydrogen compound specific isotope analyses $\left(\delta^{13} \mathrm{C}\right.$ and $\left.\delta^{2} \mathrm{H}\right)$. The total VOSC concentrations range from 0.7 to $30 \mathrm{ppm}$. The organic sulfides are mainly composed of carbonyl sulfide (COS) and diethyl sulfide. The main thiol compound is ethanethiol and the cyclic VOSCs are primarily composed of thiophene. Pearson's correlation showed a positive relationship between the total of VOSC and $\mathrm{C}_{1}-\mathrm{C}_{3}$ concentrations but did not indicate a meaningful correlation with $\delta^{13} \mathrm{C}$ and $\delta^{2} \mathrm{H}$ data. $\mathrm{H}_{2} \mathrm{~S}$ showed a strong positive Pearson's correlation with COS and methanethiol (MeSH) concentrations. This suggests that COS and $\mathrm{MeSH}$ formations are linked to $\mathrm{H}_{2} \mathrm{~S}$ generation and/or post-catagenesis interactions between hydrocarbons and $\mathrm{H}_{2} \mathrm{~S}$. The highest $\mathrm{H}_{2} \mathrm{~S}$ concentrations in the Santos Basin have been attributed to thermochemical sulfate reduction (TSR) [2]. This indicates a possible link between $\mathrm{COS}$ and MeSH generation and TSR. Nevertheless, the higher molecular weight VOSC seems to be controlled by organic facies and thermal maturity, rather than $\mathrm{H}_{2} \mathrm{~S}$ concentration. Principal component analysis of the VOSC's compositional data allows for the separation of gas families in the Santos Basin, supporting the idea of their applicability in petroleum system studies. [1] Cai et al. (2003). Chem. Geol. 202, 39-57. [2] Santos Neto et al. (2013). Annual Offshore Technology Conference. OTC-24368-MS. 